\title{
O PROCESIE RACJONALIZACJI WYDATKÓW PUBLICZNYCH
}

\section{UWAGI WPROWADZAJĄCE}

Dotychczasowe próby analizy racjonalizacji wydatków publicznych nie były kompleksowe bądź odnosiły się wyłącznie do niektórych zagadnień związanych z tą kwestią. Wyjąwszy bardzo cenne opracowanie Ekonomiczne i prawne problemy racjonalizacji wydatków publicznych ${ }^{1}$ pod redakcją Jana Głuchowskiego, Alicji Pomorskiej i Jolanty Szołno-Koguc, w polskiej literaturze prawniczej i ekonomicznej bardzo trudno znaleźć opracowanie monograficzne skupiające się gruntownie na powyższym temacie. Należy zauważyć, iż sposoby wydatkowania środków publicznych zawsze budziły zainteresowanie, które nie przełożyło się jednak na pełne wyjaśnienie pojęcia racjonalizacji wydatków publicznych, określenie różnic między racjonalizacją wyborów a racjonalizacja kosztów, a ponadto na ostateczne ustalenie, czy każde działanie oszczędnościowe można określić mianem racjonalizacji wydatków publicznych. Niniejszy artykuł ma na celu omówienie powyższych problemów.

\section{POJĘCIE RACJONALIZACJI W JĘZYKU PRAWNYM I PRAWNICZYM}

W języku prawnym nie istnieje legalna definicja racjonalizacji. Wspomniany termin nie występuje zbyt często w źródłach prawa ${ }^{2}$. Język prawniczy, czyli język, w którym wypowiadają się prawnicy ${ }^{3}$, również nie daje jednoznacznej odpowiedzi na pytanie, czym jest racjonalizacja. Pomimo iż sądy oraz przed-

1 J. Głuchowski, A. Pomorska, J. Szołno-Koguc (red.), Ekonomiczne i prawne problemy racjonalizacji wydatków publicznych, t. 1: Racjonalizacja wydatków publicznych - uwarunkowania $i$ instrumenty, Lublin 2005; J. Głuchowski, A. Pomorska, J. Szołno-Koguc (red.), Ekonomiczne i prawne problemy racjonalizacji wydatków publicznych, t. 2: Kontrowersje wokół wydatkowania środków publicznych w wybranych dziedzinach funkcjonowania państwa $i$ gospodarki narodowej, Lublin 2005.

${ }^{2}$ Rezultatem wyszukiwania przeprowadzonego w systemie informacji prawnej Lex Prestige za pomocą hasła „racjonalizacja” i kryterium mocy obowiązującej było ustalenie, że wspomniany zwrot nie został użyty w żadnej obecnie obowiązującej ustawie - stan z 20 maja 2015 r.

${ }^{3}$ T. Gizbert-Studnicki, Język prawny $z$ perspektywy socjolingwistycznej, „Zeszyty Naukowe Uniwersytetu Jagiellońskiego. Prace z Nauk Politycznych” 1986, z. 26, s. 33 i 34. 
stawiciele doktryny wielokrotnie odwołuja się do pojęcia „racjonalizacja”, to częstokroć czynią to w zupełnie różnych kontekstach, co uniemożliwia jego właściwe zdefiniowanie ${ }^{4}$. Zwrot ten używany jest do opisywania zjawisk występujących w różnych dziedzinach życia i prawa. Tytułem przykładu można także podać wiele publikacji ${ }^{5}$ dotyczących racjonalizacji na gruncie ustawy z 30 czerwca 2000 r. - Prawo własności przemysłowej ${ }^{6}$ oraz ustawy z 19 października 1972 r. o wynalazczości ${ }^{7}$, a także racjonalizacji poszczególnych gałęzi prawa ${ }^{8}$.

\section{POJĘCIE RACJONALIZACJI W JĘZYK POWSZECHNYM I EKONOMII}

W celu właściwego określenia racjonalizacji należy zatem sięgnąć do języka powszechnego, względnie do innych dziedzin nauki ${ }^{9}$ Termin „racjonalizacja” wywodzi się z łacińskich słów ratio, rationalis ${ }^{10}$, które oznaczają odpowiednio „rozum”, „rozsądek” oraz „rozumny”, „rozsądny”. Nowy stownik języka polskiego $\mathrm{PWN}^{11}$, a także Inny stownik języka polskiego $\mathrm{PWN}^{12}$ podają zbieżne znaczenia analizowanego zwrotu. Podobnie Stownik wyrazów obcych $\mathrm{PWN}^{13}$ ujmuje racjonalizację jako podejmowanie środków ukierunkowanych na usprawnienie danej działalności. Co istotne i zasługuje na szczególne podkreślenie, w naukach ekonomicznych wykształciło się zgoła odmienne znaczenie racjonalizacji. Według Karola Adamieckiego do międzynarodowego języka naukowego racjonalizację wprowadzili niemieccy uczeni, którzy traktowali ją jako metodę zmierzająca do osiagnięcia jak najlepszych efektów przy jak najmniejszych nakładach sił i środków ${ }^{14}$. Podobne wyjaśnienie tego pojęcia można odnaleźć w Nowym stowniku ekonomicznym dla przedsiębiorcy ${ }^{15}$. Z kolei Encyklopedia ekonomiczno-rolnicza ${ }^{16}$, definiując „,racjonalizację pracy”, wskazuje, że jest to uzyskanie możliwie maksymalnej pracy w danych warunkach bez uszczerbku dla jej jakości. Współcześnie, na gruncie finansów publicznych oraz prawa finansowego, racjonalizacja rozumiana jest znacznie szerzej.

${ }^{4}$ Por. np. postanowienie SN z 4 lipca 2007 r., V KK 419/06, Lex, nr 309729.

5 Zob. M. Du Vall, Racjonalizacja w świetle prawa wynalazczego, Wrocław 1989; M. Staszków, A. Szewc (red.), Wynalazczość i racjonalizacja: poradnik dla nauczycieli, Katowice 1986; zob. tė̇ O. Raban, Racjonalizacja polityki: o zwiazku między demokracja a rzqdami prawa, tłum. A. M. Baziór, „Ruch Prawniczy, Ekonomiczny i Socjologiczny” 76, 2014, z. 4, s. 26-29.

${ }_{6}$ Dz. U. 2003, Nr 119, poz. 1117.

7 Dz. U. 1993, Nr 26, poz. 117.

${ }^{8}$ Por. np. J. Łukasiewicz, $Z$ zagadnień racjonalizacji tworzenia prawa administracyjnego (wybrane uwagi), w: E. Bojanowski (red.), Legislacja administracyjna, Gdańsk 1993, s. 129-136.

9 Wyrok NSA z 14 grudnia 2000 r., FSA 2/00, Legalis.

10 Stownik wyrazów obcych PWN, red. J. Tokarski, Warszawa 1980, s. 620.

11 Nowy słownik języka polskiego PWN, red. E. Sobol, Warszawa 2002, s. 821.

12 Inny słownik języka polskiego PWN, P-Ż, red. M. Bańko, Warszawa 2000, s. 406.

13 Stownik wyrazów obcych PWN, red. L. Drabik, Warszawa 2009, s. 769.

${ }^{14}$ K. Adamiecki, Nauka organizacji i jej rola $w$ życiu gospodarczym, Warszawa 1932, s. 6.

15 Nowy stownik ekonomiczny dla przedsiębiorcy, red. Z. Dowgiałł, Szczecin 2004, s. 314.

${ }_{16}$ Encyklopedia ekonomiczno-rolnicza, red. R. Manteuffel, Państwowe Wydawnictwo Rolnicze i Leśne, Warszawa 1984, s. 626. 
Badany termin jest wieloznaczny, co może wywołać sporo wątpliwości interpretacyjnych. Przechodził on i nadal przechodzi ewolucje, nie tylko jeśli chodzi o nazwę, lecz również o zakres definicyjny. Wydaje się, że obecnie z uwagi na historię Rzeczypospolitej Polskiej racjonalizacja częściej jest kojarzona z okresem istnienia Polskiej Rzeczypospolitej Ludowej, aniżeli z finansami publicznymi. Warto przy tym dodać, że błędny jest pogląd jakoby racjonalizacja, rozumiana jako proces udoskonalania, usprawniania istniejących rozwiązań (technicznych, organizacyjnych itd.), była zjawiskiem powiązanym wyłącznie z ustrojem socjalistycznym, albowiem już w XIX w. funkcjonowała w Stanach Zjednoczonych i w innych wysoko rozwiniętych krajach kapitalistycznych ${ }^{17}$. Zaakcentować ponadto trzeba, że w okresie istnienia PRL przez wiele lat w ogóle nie przywiązywano większej wagi do właściwego prowadzenia publicznej gospodarki finansowej ${ }^{18}$, a racjonalizację utożsamiano z poprawą organizacji pracy ${ }^{19}$.

Chociaż nie zawsze pojęcie zdefiniowane na potrzeby ekonomii pokrywa się $\mathrm{z}$ pojęciem występującym w znaczeniu prawnym, to wobec braku wykształcenia w przepisach i naukach prawnych jednolitego znaczenia terminu „racjonalizacja” ${ }^{20}$, należy stwierdzić, że z wyżej omówionych znaczeń tylko jej ekonomiczne wyjaśnienie (tj. uzyskiwanie jak najlepszych efektów przy jak najmniejszych nakładach) będzie można częściowo wykorzystać na potrzeby wyjaśniania całego pojęcia „racjonalizacja wydatków publicznych”.

\section{POJĘCIE RACJONALIZACJI WYDATKÓW PUBLICZNYCH}

Racjonalizacja wydatków publicznych, wobec braku ustawowej definicji, może być rozpatrywana w wielu różnych aspektach. Jednym z nich jest minimalizacja wydatków na założone uprzednio zadania publiczne. Innym z kolei jest maksymalizacja efektywności wydatkowania środków publicznych. Przy czym sprzeczne logicznie będzie łączenie obu powyższych wariantów, tj. maksymalizacja celów przy minimalizacji nakładów, stąd trzeba je rozpatrywać odrębnie $^{21}$. Badanie efektywności wydatków jest jednakże trudne, a trudność ta wynika z tego, że niektóre dziedziny, na które wydatki publiczne sa ponoszone, nie sa podatne na stosowane narzędzia pomiaru ${ }^{22}$. Częstokroć nie jest możliwe ustalenie związku przyczynowo-skutkowego między strukturą i rozmiarami wydatków publicznych a osiagniętymi z ich tytułu rzeczywistymi korzyściami po stronie państwa i społeczeństwa (dotyczy to w szczególności wydatków na

17 A. Szewc, Wynalazki pracownicze w prawie polskim, Warszawa 1976, s. 7-10.

18 J. Stankiewicz, Zagadnienia racjonalizacji wydatków publicznych, w: C. Kosikowski, E. Ruśkowski (red.), Finanse publiczne, Warszawa 2008, s. 702.

${ }_{19}$ G. Bieniek, Prawne aspekty racjonalizacji zatrudnienia w warunkach reformy gospodarczej, „Praca i Zabezpieczenie Społeczne” 1982, nr 7, s. 45-53.

${ }^{20}$ J. Stankiewicz, Problemy racjonalizacji wydatków publicznych i wieloletniego planowania finansowego $w$ aspekcie budżetowania zadaniowego $i$ wieloletnich planów finansowych $w$ Polsce, w: E. Ruśkowski (red.), System prawa finansowego, t. 2: Prawo finansowe sektora finansów publicznych, Warszawa 2010, s. 269 i n.

21 O. Lange, Ekonomia polityczna, Warszawa 1978, s. 147-148.

22 J. Gliniecka, Zasada racjonalnego wydatkowania środków publicznych, „Gdańskie Studia Prawnicze” 27, 2012, s. 93. 
obronę narodowa). Aby osiagnąć cel racjonalizacji wydatków publicznych, prawodawca może stosować uproszczone bądź bardziej złożone metody. Niewątpliwie stosowanie prostych środków zmierzać będzie do eliminowania wszelkich przejawów niegospodarności i złej organizacji wydatków publicznych. Bardziej złożone modele racjonalizacji wydatków opierać się będą na długotrwałym procesie, począwszy od ustalenia możliwości finansowych państwa oraz hierarchii potrzeb, odpowiednim zaplanowaniu sposobu wydatkowania (określeniu m.in., czy dany wydatek ma zostać poniesiony $\mathrm{w}$ danym roku budżetowym, w jakiej wysokości i w jakim terminie), przez odpowiednie wdrożenie tego sposobu (wraz z ewentualnym wyborem wariantu jego realizacji), a skończywszy na nadzorze i kontroli nad przebiegiem jego wykonania. Polski ustawodawca przyjął ten drugi model, czego dowodem jest wiele obowiąujaccych ustaw (np. ustawa z 29 stycznia 2004 r. - Prawo zamówień publicznych ${ }^{23}$ ).

W doktrynie prawa finansowego i finansów publicznych pojawiają się rozbieżności co do zakresu racjonalizacji wydatków publicznych. Dlatego też warto w tym miejscu przytoczyć funkcjonujące znaczenia tego zwrotu. Zdaniem Ludmiły Lipiec-Warzechy racjonalnym wydatkowaniem środków nazywane jest dokonywanie wydatków w sposób celowy, oszczędny i terminowy ${ }^{24}$. Krzysztof Gałuszka ${ }^{25}$ mianem racjonalizacji wydatków publicznych określa procedurę maksymalizacji celów państwa przy dostępnych środkach. Odnotować należy także słowa A. Pomorskiej ${ }^{26}$, która przy racjonalizacji kładzie nacisk na wydatkowanie środków zgodnie z ustawami budżetowymi, uchwałami budżetowymi, planami finansowymi. Jolanta Szołno-Koguc zwraca natomiast uwagę na wielopłaszczyznowość racjonalizacji wydatków publicznych, w tym w szczególności na jej płaszczyznę ekonomiczna, w wariancie mikro i makro ${ }^{27}$. Niemal analogicznie ujmuje racjonalizację wydatków publicznych Elżbieta Kornberger-Sokołowska ${ }^{28}$. Przez pojęcie racjonalizacji wydatków publicznych, zdaniem niektórych badaczy, można rozumieć także rozsądne i przemyślane działania, które przynoszą określone efekty ekonomiczne i polityczne w zakresie dysponowania środkami publicznymi ${ }^{29}$. W literaturze przedmiotu ${ }^{30}$ można

23 Dz. U. 2013, poz. 907 (dalej jako: u.p.z.p.).

${ }^{24}$ L. Lipiec-Warzecha, Komentarz do art. 44 ustawy o finansach publicznych, Lex/el 2011.

${ }_{25} \mathrm{~K}$. Gałuszka, Wspótpraca jednostek samorzadu terytorialnego jako forma racjonalizacji wydatków publicznych, w: A. Pomorska (red.), Instytucje, instrumenty i strategie finansowe $w$ dobie integracji gospodarczej, Lublin 2006, s. 413-422.

${ }_{26}$ A. Pomorska, Główne uwarunkowania procesu racjonalizacji wydatków publicznych, w: J. Głuchowski, A. Pomorska, J. Szołno-Koguc (red.), Uwarunkowania i bariery w procesie naprawy finansów publicznych, Lublin 2007, s. 321-331.

27 J. Szołno-Koguc, Racjonalność wydatków publicznych a realizacja budżetowej zasady jedności, w: J. Głuchowski, J. Szołno-Koguc, A. Pomorska (red.), Ekonomiczne i prawne problemy..., t. 1 , s. 140 .

${ }_{28}$ E. Kornberger-Sokołowska, Absorpcja środków Unii Europejskiej a racjonalizacja wydatków publicznych, w: J. Głuchowski, J. Szołno-Koguc, A. Pomorska (red.), Ekonomiczne i prawne problemy..., t. 1, s. 161.

29 S. Owsiak, Metody budżetowania sfery nieprodukcyjnej, Kraków 1983, s. 13.

${ }^{30}$ A. Pomorska, Racjonalizacja wydatków publicznych jako niezbędny $i$ istotny warunek naprawy finansów publicznych w Polsce, w: I. Czaja-Hilniak (red.), Nauka prawa finansowego po I dekadzie XXI wieku. Ksiega pamiatkowa dedykowana Profesorowi Apoloniuszowi Kosteckiemu, Kraków 2012, s. 348. 
napotkać twierdzenia, jakoby racjonalizacja wydatków publicznych składała się z trzech następujących po sobie etapów realizacji wydatków - 1) wyboru dofinansowania zadań, których realizacja zaspokoi najbardziej użyteczne społecznie potrzeby, 2) określenia kosztów realizacji zadania oraz 3) wykorzystania środków publicznych z uwzględnieniem efektywności ekonomicznej ${ }^{31}$.

Widoczna jest różnica w stanowiskach przedstawicieli doktryny prawa finansowego, dotyczących procesu racjonalizacji wydatków publicznych. Polega ona m.in. na odnoszeniu tego procesu wyłacznie do wykonywania zadań publicznych bądź łączeniu go z kształtowaniem struktury wydatków. Poza tym dostrzec trzeba, że właściwie każda z interpretacji kładzie nacisk na zupełnie inny aspekt racjonalizacji (albo na celowe, oszczędne i terminowe wydatkowanie środków, albo na uzyskiwanie jak najlepszych efektów przy jak najmniejszych nakładach). Świadczy to o kompleksowości i subiektywności tego zwrotu. Pewne jest natomiast to, że sama racjonalizacja nie powinna być oceniana głównie przez pryzmat techniki rozliczeń i trybu przekazywania środków, lecz przede wszystkim przez pryzmat konstrukcji prawnych istniejącego systemu społeczno-gospodarczego. Z dużą dozą ostrożności podchodzić należy do zamiennego stosowania pojęć „racjonalne wydatkowanie środków publicznych”, „racjonalność wydatków publicznych” czy też „racjonalizacja wydatków publicznych”, gdyż nie zawsze opisują one ten sam proces.

Zaproponowane przez J.Szołno-Koguc oraz E. Kornberger-Sokołowska określenia racjonalizacji wydatków publicznych wydają się właściwym punktem wyjścia prowadzonych badań, gdyż uwzględniają szersze, ekonomiczne uwarunkowania racjonalizacji. Racjonalność w gospodarowaniu środkami publicznymi przejawia się w dbałości o odpowiednią strukturę i rozmiar wydatków publicznych, w osiaganiu jak najlepszych rezultatów przy jak najmniejszych nakładach, a nadto w dokonywaniu optymalnych wyborów do realizacji założonych celów. Racjonalizacją wydatków publicznych objacc również należy działania, które umożliwiają uzyskiwanie jak najlepszych efektów przy danych nakładach.

\section{RACJONALIZACJA WYBORÓW I KOSZTÓW W RAMACH RACJONALIZACJI WYDATKÓW PUBLICZNYCH}

W ramach racjonalizacji wydatków publicznych wyodrębnić należy racjonalizację kosztów oraz racjonalizację wyborów, choć w literaturze przedmiotu i judykaturze stosunkowo rzadko można spotkać takie rozgraniczenie ${ }^{32}$. Kry-

${ }^{31}$ E. Denek, J. Sobiech, J. Wolniak, Finanse publiczne, Warszawa 2001, s. 112; M. Pypeć, Cele i kryteria racjonalności wydatków publicznych, w: A. Pomorska, M. Pypeć (red.), Racjonalizacja wydatków publicznych w warunkach deficytu budżetowego, Radom 2004, s. 37-40.

32 O racjonalizacji wyboru wspominają m.in. P. Soszyńska-Purtak, Zasady udzielania zamówień sektorowych poniżej wartości progowej, Lex/el 2012; podczas gdy o racjonalizacji kosztów piszą: W. Grześkiewicz, Czy samorzqdowe samodzielne zakłady opieki zdrowotnej sa w stanie ograniczyć przyrost zadtużenia, „Finanse Komunalne” 2013, nr 9, s. 24-32; T. Machelski, Racjonalność ekonomiczna jako podstawa legalności aktów normatywnych organów samorzadu terytorialnego, „Finanse Komunalne” 2011, nr 7-8, s. 5-14; A. Wagrodzka, Koncepcja marketingu terytorialnego 
terium rozróżniającym racjonalizację kosztów i wyborów jest to, czy przedmiotem badania efektywności są zadania czy pozostające do dyspozycji środki finansowe. Ta pierwsza wiąże się z realizowaniem zadań przy jak najmniejszym zaangażowaniu środków publicznych, z kolei ta druga odnosi się do wyboru spośród alternatywnie istniejących środków, które w najlepszy sposób zagwarantują realizację założonego celu. Przy racjonalizacji wyborów analizie (głównie ekonomicznej - ale nie wyłącznie) poddawane są wszystkie pozytywne i negatywne skutki istniejącej opcji. Punktem wyjścia takiego badania jest określenie wysokości prognozowanych nakładów przy zastosowaniu danej metody. Do racjonalizacji kosztów dążyć można trzema metodami: powołując scentralizowany organ zarządzający i nadzorujący jednostki sektora finansów publicznych, tworząc zasady postępowania odnoszące się do sposobu wydatkowania środków publicznych bądź łącząc oba powyższe rozwiązania ${ }^{33}$. Wspomniane wyżej wyodrębnienie ma normatywne uzasadnienie, które nie zostało literalnie wyrażone w ustawie z 27 sierpnia 2009 r. o finansach publicznych ${ }^{34}$. Aktualna u.f.p. wprost wspomina w art. 44 ust. 3 pkt 1, że wydatki publiczne powinny być dokonywane: 1) w sposób celowy i oszczędny, z zachowaniem zasad: a) uzyskiwania najlepszych efektów z danych nakładów, b) optymalnego doboru metod i środków służących osiagnięciu założonych celów.

Biorąc pod uwagę treść powyższego przepisu, można bez większych wątpliwości stwierdzić, że według ustawodawcy art. 44 ust. 3 pkt 1 lit. a u.f.p. ma służyć maksymalizacji efektów przy danych nakładach oraz minimalizacji kosztów przy porównywalnych efektach. Jest to zasada efektywności, której urzeczywistnienie następuje $\mathrm{w}$ związku $\mathrm{z}$ odpowiednim wyborem metody do realizacji celu oraz możliwie jak największym ograniczeniem wydatkowania środków publicznych przy uzyskaniu odpowiedniego rezultatu. Natomiast dobór środków i metod, o którym mowa w art. 44 ust. 3 pkt 1 lit. b u.f.p., dotyczy zasady skuteczności ${ }^{35}$, oznaczającej konieczność uzyskiwania właściwej relacji między wyznaczonymi zadaniami a osiagniętymi efektami ich realizacji. Nie jest to zatem racjonalizacja wyborów. Twórcy obecnie obowiązującej u.f.p., uzasadniając skorzystanie z wyżej wymienionej formuły, podkreślili, że rozszerzono zasady dokonywania wydatków publicznych o zasadę skuteczności (polegająca na optymalnym doborze metod i środków dla osiagnięcia założonych celów, przy celowym i oszczędnym dokonywaniu wydatków), będąca jednocześnie podstawową zasadą budżetu zadaniowego ${ }^{36}$. Każdy wydatek, który ma być efektywny, musi również wywoływać odpowiednie skutki. Nie zawsze jednak zrealizowanie określonego zadania i wypełnienie zasady skuteczności jednocześnie będzie oznaczać, że wydatki na to zadanie poniesione zostały w sposób efektywny (uzyskanie optymalnej relacji między wykonanym

a oczekiwania członka wspólnoty samorzadowej, „Samorząd Terytorialny” 2004, nr 12, s. 24-39; A. Jakubowicz, Analiza poziomu wynagradzania nauczycieli na przykładzie powiatu świebodzińskiego, „Samorząd Terytorialny” 2006, nr 11, s. 47 i n.

${ }_{33}$ J. Stankiewicz, Zagadnienia racjonalizacji..., w: C Kosikowski, E. Ruśkowski (red.), op. cit., s. 708.

${ }^{34}$ Dz. U. 2013, poz. 885 (dalej jako: u.f.p.).

35 Ibidem, s. 702.

${ }^{36}$ Uzasadnienie do rządowego projektu ustawy o finansach publicznych, druk sejmowy nr 1181 Sejmu VI kadencji, www.sejm.gov.pl [dostęp: 20.05.2015]. 
zadaniem a poniesionymi nakładami). Dlatego w art. 44 ust. $3 \mathrm{w}$ pkt 1 u.f.p. wyrażono zarówno zasadę skuteczności, jak i efektywności.

Istotne jest zaznaczenie, że racjonalizacja wyborów może dotyczyć procedury wyboru wydatku, który ma zostać poniesiony (racjonalizacja wyborów budżetowych), lub procedury wyboru sposobu realizacji danego zadania. Pierwsza procedura przeprowadzana jest na etapie prognozowania i planowania finansowego, najczęściej według kryterium możliwości dokonania wydatku oraz poziomu użyteczności publicznej ${ }^{37}$. Racjonalizacja wyborów odnosząca się do zadań dotyczy z kolei fazy wykonawczej, gdy decyzja co do poniesienia danego wydatku publicznego została już uprzednio podjęta i potrzebny jest wybór optymalnego wariantu realizacji. Przy czym przez wspomniane wyżej warianty należy rozumieć m.in. konstrukcje prawne, które zostaną wykorzystane do zrealizowania zadania (celu).

Należy jednocześnie wspomnieć o tym, że dzielenie racjonalizacji wydatków na racjonalizację wyborów i kosztów jest istotne z punktu widzenia kryteriów kontroli. Nie są one dość ostre i wystarczająco doprecyzowane w przepisach prawnych $^{38}$. Dotyczy to zwłaszcza gospodarności, która ma największą doniosłość prawna. Najczęściej w literaturze przedmiotu można spotkać się z twierdzeniem, że wspomniane wyżej kryterium obejmuje racjonalizację wyborów i kosztów. Niektórzy autorzy zaliczają jednak racjonalizację wyboru do kryterium celowości (celowość metodyczna, polegająca na trafności wyboru środka, który posłuży do realizacji celu), a racjonalizację kosztów do kryterium gospodarności ${ }^{39}$. Racjonalizację kosztów i wyborów (tak jak i całą racjonalizację wydatków) objać jednakże trzeba jednym kryterium - gospodarności. Celowość w ujęciu finansowym winna być powiązana z zasadą skuteczności (wybór właściwych środków do realizacji celów - niekoniecznie optymalnych, a więc najlepszych w możliwych warunkach ${ }^{40}$ ), a co za tym idzie - sprawdzana tylko przez weryfikację, czy i w jakim stopniu środki finansowe zostały wydatkowane zgodnie $\mathrm{z}$ ustalonym przeznaczeniem ${ }^{41}$.

\section{INSTRUMENTY PRAWNE RACJONALIZACJI WYDATKÓW PUBLICZNYCH}

W obecnie obowiązujących przepisach nie istnieje legalna definicja „instrumentu prawnego", aczkolwiek w aktach normatywnych spotykany jest ten zwrot, najczęściej bez jego wyjaśnienia. Tytułem przykładu można podać art. 4

\footnotetext{
${ }^{37}$ M. Jastrzębska, Finanse jednostek samorzqdu terytorialnego, Warszawa 2012, s. 140 i n.

${ }_{38}$ J. Glumińska-Pawlic, Samodzielność finansowa jednostek samorzqdu terytorialnego $w$ Polsce, Katowice 2003, s. 235.

${ }^{39}$ B. Banaszek, Konstytucja Rzeczypospolitej Polskiej. Komentarz, Warszawa 2012, s. 1006; Z. Witkowski (red.), Prawo konstytucyjne, Toruń 2011, s. 604.

${ }^{40}$ E. Jarzęcka-Siwik, B. Skwarka, Najwyższa Izba Kontroli. Komentarz do ustawy o Najwyższej Izbie Kontroli, Warszawa 2011, s. 48.

${ }^{41}$ J. Uryga, W. Jagielski, I. Bienias, Środki unijne klasyfikacja, funkcjonowanie, ewidencja i rozliczanie, Gdańsk 2007, s. 211.
} 
ust. 3 ustawy z 6 grudnia 2006 r. o zasadach prowadzenia polityki rozwoju ${ }^{42}$ lub ustawę z 27 kwietnia 2001 r. - Prawo ochrony środowiska ${ }^{43}$, gdzie dział czwarty drugiego tytułu został określony jako: „Instrumenty prawne służące przeciwdziałaniu poważnej awarii przemysłowej”. Dzieje się tak z racji uniwersalności analizowanego terminu. Podkreślić tu wypada, że w wielu gałęziach prawa ugruntowane zostało znaczenie ,instrumentu prawnego”. W publicznym prawie gospodarczym „instrumenty prawne” to narzędzia, za pomoca których podmioty publiczne osiagają określone cele przez ingerencję w sferę gospodarki. Według Kazimierza Strzyczkowskiego forma prawna jest z kolei zewnętrznym wyrazem zastosowanego instrumentu prawnego ${ }^{44}$. Omawiany zwrot jest używany w odniesieniu do regulacji prawnych o różnych formach i szerokim zakresie. W prawie administracyjnym podkreśla się, że administracja publiczna do wykonywania zadań wykorzystuje wiele instrumentów prawnych, które określa się mianem form działania administracji ${ }^{45}$. Najogólniej rzecz ujmujacc, instrument prawny to norma lub zespół norm prawnych umożliwiających osiąnnięcie określonych celów. W przypadku racjonalizacji wydatków publicznych wspomniane cele mogą być bardzo różne w zależności od tego, które rozumienie racjonalizacji uzna się za właściwe.

Należy w tym miejscu postawić jeszcze pytanie o instrumenty racjonalizacji wyborów i kosztów. Większych trudności nie nastręcza odnalezienie drugiej grupy przepisów. Na pierwszy plan wysuwa się tutaj ustawa p.z.p., dzięki której podmioty publiczne mogą uzyskiwać jak najlepsze rezultaty przy możliwie jak najniższych kosztach ${ }^{46}$. Problemy pojawiają się natomiast przy okazji racjonalizacji wyborów, rozumianej jako proces doboru wydatku, który ma zostać poniesiony, a nadto wyboru formy działania, która zagwarantuje realizację celu (zadania) w najbardziej efektywny sposób. Możliwość posługiwania się przez państwo oraz przez jednostki samorządu terytorialnego działaniami władczymi (akty administracyjne, w tym m.in. decyzje administracyjne), jak i niewładczymi (umowy cywilnoprawne, umowy administracyjne, porozumienia administracyjne ${ }^{47}$ ) jest bowiem warunkowana odpowiednimi przepisami, a wybór między nimi jest ograniczony ${ }^{48}$. To samo dotyczy publicznoprawnych i cywilnoprawnych form działania. Za instrumenty prawne racjonalizacji wyborów będzie można uznać przepisy regulujące kwestie związane $\mathrm{z}$ budżetem zadaniowym, wieloletnim planem finansowym, obowiązkiem przeprowadzania badań i prognoz ekonomicznych co do każdego z wariantów działania, ewentualnie także przepisy regulujące zasady kontroli, nadzoru i odpowiedzialności za zarządzanie środkami publicznymi. W polskim porządku prawnym nie występują właściwie przepisy nakazujące przeprowadzenie prognozy ekonomicznej co do każdego z możliwych wariantów realizacji zada-

${ }^{42}$ Dz. U. 2009, Nr 84, poz. 712.

${ }^{43}$ Dz. U. 2008, Nr 25, poz. 150.

${ }^{44}$ K. Strzyczkowski, Prawo gospodarcze publiczne, Warszawa 2005, s. 205.

45 J. Zimmermann, Prawo administracyjne, Warszawa 2006, s. 282; J. Starościak, Prawne formy działania administracji, Warszawa 1957, s. 14.

${ }_{46}$ Orzeczenie GKO z 13 lutego 2003 r., DF/GKO/Odw.-134/170-171/2002, Lex, nr 80068.

${ }^{47}$ J. Zimmermann, op. cit., s. 284.

48 E. Ochendowski, Prawo administracyjne. Część ogólna, Toruń 2002, s. 26. 
nia. Budżety i wieloletnie plany finansowe służą bowiem do wyboru wydatku, który ma zostać poniesiony w danej perspektywie finansowej, a nie do doboru odpowiedniej metody i sposobu realizacji celu.

Instrumenty prawne racjonalizacji wydatków publicznych to środki określone w obowiązujących przepisach prawnych, za pomocą których państwo i jednostki samorządu terytorialnego mogą realizować cele w postaci odpowiedniego ukształtowania struktury i rozmiaru wydatków publicznych (zwłaszcza poprzez ustalenie zadań priorytetowych oraz pobocznych), efektywnego wyboru spośród alternatywnie istniejących, sposobu realizacji tychże zadań, maksymalizacji wyników przy danych nakładach, minimalizacji kosztów przeznaczanych na osiagnięcie określonego celu ${ }^{49}$ (oczywiście głównym celem racjonalizacji pozostaje wciąż ograniczenie wydatków publicznych). Konsekwencją tego będzie stwierdzenie, że podstawowymi instrumentami prawnymi, służącymi racjonalizacji wydatków publicznych, będą budżet zadaniowy, Wieloletni Plan Finansowy Państwa, przepisy regulujące współpracę między jednostkami samorządu terytorialnego, procedury przetargowe zgodnie z ustawą p.z.p., ustawą z 9 stycznia 2009 r. o koncesji na roboty budowlane lub usługi ${ }^{50}$, procedury konkursowe według ustawy z 24 kwietnia 2003 r. o działalności pożytku publicznego i o wolontariacie ${ }^{51}$ czy ustawy z 27 sierpnia $1997 \mathrm{r}$. o rehabilitacji zawodowej i społecznej oraz zatrudnianiu osób niepełnosprawnych ${ }^{52}$, kontrola zarządcza, audyt wewnętrzny, przepisy dotyczące odpowiedzialności za naruszenie dyscypliny finansów publicznych ${ }^{53}$. Oczywiście niektóre instrumenty będą występowały wyłącznie na poziomie krajowym bądź samorządowym (np. przepisy regulujące współpracę między jednostkami samorządu terytorialnego). W zależności od funkcji, jaką mają spełniać, zasygnalizować trzeba podział na instrumenty planistyczne, zakazu, nakazu (prewencyjne) i represyjne ${ }^{54}$.

Ilość rozwiązań prawnych, które moga, choćby pośrednio, pozytywnie wpłynąć na wydatki publiczne, jest praktycznie nieograniczona. Nie sposób ich wszystkich omówić, a nawet wymienić w niniejszej pracy. Na potwierdzenie tej tezy można podać okoliczność, iż nawet konstytucyjne rozwiązania dotyczące zakazu zaciagania pożyczek lub udzielania gwarancji i poręczeń finansowych, w następstwie których państwowy dług publiczny przekroczy 3/5 wartości rocznego produktu krajowego brutto (art. 216 ust. 5 Konstytucji $\mathrm{RP}^{55}$ ), zakazu ustalania większego deficytu budżetowego niż przewidziany w projekcie budżetu (art. 220 ust. 1 Konstytucji RP) oraz zakazu pokrywania deficytu budżetowego przez zaciaganie zobowiązania w centralnym banku państwa (art. 220 ust. 2 Konstytucji RP) - mogą zostać uznane za pewien rodzaj instrumentów

${ }^{49} \mathrm{H}$. Sochacka-Krysiak, Wybrane problemy racjonalizacji wydatków publicznych na finansowanie usług społecznych, w: T. Juja, J. Kotlińska (red.), Stan i kierunki rozwoju finansów publicznych, Poznań 2007, s. 121-122.

${ }^{50}$ Dz. U. 2009, Nr 19, poz. 101.

${ }^{51}$ Dz. U. 2003, Nr 96, poz. 873.

${ }_{52}$ Dz. U. 2011, Nr 127, poz. 721.

${ }_{53}$ M. Jastrzębska, op. cit., s. 141.

${ }^{54}$ K. Owsiak, Koncepcja bezpieczeństwa finansów publicznych, w: A. Pomorska (red.), Instytucje, instrumenty..., s. 413-422

${ }_{55}$ Dz. U. 1997, Nr 78, poz. 483. 
prawnych racjonalizacji wydatków publicznych odnoszących się do właściwego ukształtowania struktury wydatków ${ }^{56}$. Wyjątków nie należy bowiem czynić dla kosztów obsługi państwowego długu publicznego ${ }^{57}$ (gdyż forma i warunki zadłużenia mogą być bardzo zróżnicowane, a w tym zakresie władza publiczna również powinna postępować racjonalnie), a także dla bezrefleksyjnego zaciągania zobowiązań przez państwo i jednostki samorządu terytorialnego ${ }^{58}$. Innymi instrumentami racjonalizacji mogą być autoryzacja wydatków na etapie uchwalania budżetu i kontrola jego wykonania ${ }^{59}$.

\section{WNIOSKI}

W konkluzji poczynionych rozważań należy stwierdzić, że pojęcie racjonalizacji wydatków publicznych cechuje duży poziom złożoności i subiektywności. Dlatego konieczne jest jej rozpatrywanie na płaszczyznach prawnej, ekonomicznej i socjologicznej. Wniosek ten jest tym bardziej zasadny, że omawiane pojęcie $\mathrm{w}$ języku prawnym nie zostało zdefiniowane, a w języku prawniczym można spotkać się z różnymi wyjaśnieniami tego zjawiska (nie zawsze zbieżnymi).

Taki stan rzeczy wynika zapewne z okoliczności, że zjawiska (procesy) racjonalizacji wydatków publicznych obejmują bardzo szeroki katalog instrumentów prawnych, a zarazem wywołują różnorodne skutki w sferze ekonomicznej. W rezultacie niektórzy przedstawiciele doktryny prawa finansowego większą uwagę przywiąują do uzyskiwania jak najlepszych efektów z danych nakładów, a inni do dokonywania wydatków publicznych w sposób zgodny z zasadami gospodarki finansowej. Podkreślić wypada, że nie każde działanie, które spowodowało obniżenie poziomu wydatków publicznych, powinno być kwalifikowane jako racjonalizacja wydatków publicznych ${ }^{60}$. Nie sposób też utożsamiać racjonalizacji wyłącznie z oszczędnościami i cięciami, gdyż w ostateczności mogłoby to doprowadzić do zaniechania wykonywania zadań publicznych przez państwo i jednostki samorządu terytorialnego lub poważnego obniżenia ich standardów (tzw. pseudooszczędności - mogące przejawiać się np. w eliminowaniu kosztów eksploatacji dróg, które w efekcie prowadzą do zwiększonej ilości wypadków samochodowych, a w konsekwencji do zwiększo-

\footnotetext{
${ }^{56}$ A. Pomorska, Racjonalizacja wydatków..., w: I. Czaja-Hilniak (red.), op. cit., s. 348 i n.

${ }^{57}$ C. Kosikowski, Polskie prawo finansowe na tle prawa Unii Europejskiej, Warszawa 2008, s. 355 .

${ }^{58}$ M. Zdebel, Prawno-finansowe ograniczenia $w$ dostepie do kredytów bankowych jako metoda racjonalizacji finansów jednostek samorzqdu terytorialnego, w: A. Pomorska (red.), Ekonomiczne $i$ prawne uwarunkowania $i$ bariery redukcji deficytu budżetowego $i$ dtugu publicznego, Warszawa 2011, s. 519.

${ }^{59}$ K. Surówka, M. Kosek-Wojnar, Dylematy racjonalizacji wydatków publicznych jednostek samorzqdu terytorialnego, w: J. Głuchowski, A. Pomorska, J. Szołno-Koguc (red.), Ekonomiczne i prawne problemy..., t. 2 , s. 177.

${ }^{60}$ Por. R. Huterski, Indywidualistyczne podejście do racjonalizacji wydatków publicznych, w: J. Głuchowski, A. Pomorska, J. Szołno-Koguc (red.), Ekonomiczne i prawne problemy..., t. 1, s. 106 .
} 
nych wydatków na ochronę zdrowia) ${ }^{61}$. Zresztą jak pokazują badania, nawet drastyczne ograniczenie wydatków na inwestycje oraz na utrzymanie nie zawsze musi przekładać się pozytywnie na wysokość zadłużenia ${ }^{62}$. Wszelkiego rodzaju zabiegi i operacje księgowe, obniżajace poziom państwowego długu publicznego wyłącznie w ujęciu statystycznym, również nie są racjonalizacją. Zamiana długu jawnego w dług ukryty negatywnie oddziałuje na gospodarkę państwa ze względu na to, że stwarza miejsce na nowe wydatki publiczne (które często mogą być bezproduktywne), a przez to prowadzi do wzrostu państwowego długu publicznego.

Tym samym racjonalizację wydatków publicznych będzie można uznać za działanie oszczędnościowe, jednak odwrotna zależność już nie zachodzi (tj. nie każde działanie oszczędnościowe będzie racjonalizacja). Wprowadzenie stosownych dystynkcji w tym zakresie możliwe będzie po przeanalizowaniu całokształtu okoliczności stanu faktycznego, spośród których największe znaczenie będzie miało to, czy ograniczenie lub wyeliminowanie niektórych wydatków publicznych miało rzeczywisty charakter i czy wpłynęło negatywnie na funkcje i zadania państwa.

Powyższe wątpliwości nie stoją jednakże na przeszkodzie do stworzenia oraz funkcjonowania instrumentów prawnych ukierunkowanych na realizację celów racjonalizacji. Nie wdając się w analizę ich skuteczności, wypada zauważyć, że zrozumienie, czym jest i na czym polega prawidłowy proces racjonalizacji wydatków, przełoży się na wprowadzenie efektywniejszych środków prawnych. Nie sposób bowiem tworzyć norm prawnych, które mają prowadzić do racjonalizacji, nie rozumiejac jej istoty. W przeciwnym wypadku istnieje ryzyko, że zakresem powyższego pojęcia objęte będą odpowiednie zabiegi księgowe wpływajace na obniżenie długu publicznego bądź zmniejszenie liczby wykonywanych zadań publicznych (połączonych ze zmniejszeniem wysokości wydatków publicznych).

dr Maciej Gazda

maciejgazda1@gmail.com

\section{ON THE PROCESS OF RATIONALISATION OF PUBLIC EXPENDITURE}

Sum mary

The aim of this paper is presentation of the term rationalisation of public expenditure, determination of the differences between rationalisation of choices and rationalisation of costs, and furthermore establishment whether each saving act equals to the rationalisation of public expenditure. The author has focused in particular on the analysis of the expression - rationalisation in terms of legal, legalese, colloquial and economic language and present the process of public expenditures rationalisation.

${ }^{61}$ W. Misią, Mierzenie zadań publicznych jako podstawa planowania budzetowego, w: J. Głuchowski, A. Pomorska, J. Szołno-Koguc (red.), Ekonomiczne i prawne problemy..., t. 1, s. 156.

${ }^{62}$ A. Czudec, R. Kata, Zadtużenie a sytuacja ekonomiczna i ryzyko finansowe jednostek samorzqdu terytorialnego, „Finanse Komunalne” 2013, nr 5, s. 13. 
